\title{
STRATEGI MANAJEMEN RISIKO PADA BISNIS PERJALANAN DI MASA PANDEMI COVID-19
}

\author{
Adam Alif Adrian Syafruddin1, I Putu Esa Widaharthana ${ }^{2 *}$ \\ 1Program Studi Manajemen Bisnis Perjalanan, Politeknik Pariwisata Bali \\ Jl. Dharmawangsa, Benoa, Kec. Kuta Sel., Kabupaten Badung, Bali 80361, Indonesia \\ 2Program Studi Bisnis Hospitaliti, Politeknik Pariwisata Bali \\ Jl. Dharmawangsa, Benoa, Kec. Kuta Sel., Kabupaten Badung, Bali 80361, Indonesia \\ 1adamadrian98@gmail.com,2iputuesa@ppb.ac.id \\ *Corresponding author
}

\begin{tabular}{l|l|l} 
Received: August, 2021 & Accepted: August, 2021 & Published: September, 2021
\end{tabular}

\begin{abstract}
Risks in the travel business company has been widely identified at this time to the pandemic requires attention and priority handling to overcome huge losses experienced by different companies. Risk management is one of the important elements in running the company's business, especially in the field of travel business because of the growing world of the company, the increasingly fierce competition, and the increasing complexity of company activities resulting in the increasing level of risk faced by the company. The purpose of writing this article is to explain the concept of risk management and risk management in a company or organization. The writing method is based on literature review. This research uses qualitative research methods through netnographic data, namely analysis to explore a phenomenon in a group. Qualitative analysis techniques to be able to determine the right results and strategies regarding the handling of Covid-19 in Indonesia, especially in the field of travel. The findings of this study provide recommendations for implementing a naturebased rural tourism model that minimizes the scope of the crowd but still looks attractive with various packaging activities carried out by tourism actors in the village.
\end{abstract}

Keywords: risk management, risk, business travel, pandemic, Covid-19

\begin{abstract}
Abstrak
Risiko dalam perusahaan bisnis perjalanan telah banyak teridentifikasi di masa pandemi kali ini membutuhkan perhatian dan penanganan prioritas untuk menanggulangi kerugian besar yang dialami oleh berbagai perusahaan. Manajemen risiko merupakan salah satu elemen penting dalam menjalankan bisnis perusahaan terutama di bidang bisnis perjalanan karena semakin berkembangnya dunia perusahaan, adanya persaingan yang semakin ketat, serta meningkatnya kompleksitas aktivitas perusahaan yang mengakibatkan meningkatnya tingkat risiko yang dihadapi perusahaan. Tujuan dari penulisan artikel ini adalah untuk menjelaskan konsep manajemen risiko dan pengelolaan risiko di perusahaan ataupun organisasi. Metode penulisan berdasarkan kajian pustaka melalui Penelitian ini menggunakan metode penelitian kualitatif melalui data netnografi yakni analisis untuk
\end{abstract}


syafruddin, Widaharthana

mendalami suatu fenomena pada sebuah kelompok. Teknik Analisa dengan kualitatif untuk dapat menentukan hasil dan strategi yang tepat mengenai penanggulangan Covid-19 di Indonesia khususnya pada bidang perjalanan. Temuan penelitian ini memberikan rekomendasi untuk mengimplementasikan model pariwisata Pedesaan berbasis alam yang memperkecil ruang lingkup kerumunan namun tetap terlihat menarik dengan berbagai pengemasan kegiatan yang dilaksanakan oleh pelaku pariwisata di desa.

Kata Kunci: manajemen risiko, risiko, bisnis perjalanan, pandemi, Covid-19

\section{PENDAHULUAN}

Bisnis perjalanan merupakan salah satu bisnis yang mengalami perkembangan pesat dari masa ke masa, hal ini dilihat dari semakin banyaknya masyarakat yang melaksanakan perjalanan baik dalam suatu wilayah hingga ke luar daerah menggunakan transportasi pribadi maupun umum. Bisnis perjalanan berkaitan dengan pariwisata dalam pelaksanaanya. Pelaksanaan perjalanan pariwisata, mengalami peningkatan yang signifikan sejak tahun 2009 hingga 2019.

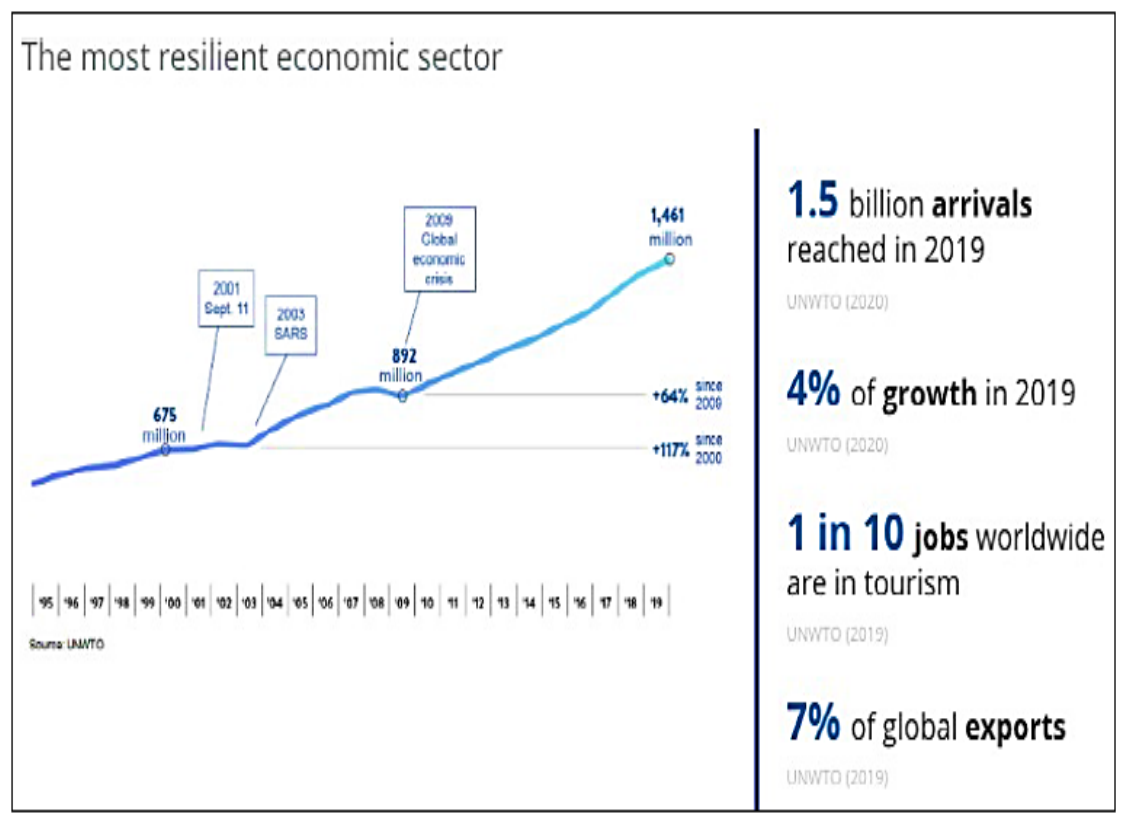

Gambar 1 : Perkembangan Pariwisata dunia pada tahun 2009-2019

[Sumber : UNWTO, 2020]

Melalui grafik gambar 1 dijelaskan bahwa pergerakan pariwisata sangatlah pesat dimana wisatawan dapat melaksanakan perjalanan hingga ke berbagai belahan dunia. Sehingga bisnis perjalanan khususnya yang berkaitan dengan pariwisata menjadi salah satu bisnis paling populer dan masuk ke dalam 10 besar bisnis yang menjanjikan di dunia. Namun bisnis perjalanan yang dulunya merupakan bisnis yang menjanjikan kehilangan daya bertahannya dikarenakan Pandemi Covid-19. Bisnis perjalanan yang berkaitan dengan bisnis pariwisata rentan terhadap risiko. Berbagai risiko yang terjadi di dunia pariwisata memerlukan pengelolaan yang baik karena kerap kali terjadi secara tak terduga dengan dipicu oleh berbagai faktor seperti risiko bencana alam, kejahatan, kesehatan dan keselamatan, 
faktor politik, sosio-demografi, risiko teknologi dan ekonomi. Di Indonesia, efek pandemi Covid-19 memiliki dampak yang signifikan karena membawa penurunan tingkat kunjungan wisatawan, hal ini dapat dilihat melalui data Badan Pusat Statistika yang berkaitan dengan jumlah kunjungan wisatawan mancanegara yang mengalami penurunan signifikan dengan penjelasan melalui tabel berikut :

Tabel 1: Jumlah Kunjungan Wisatawan Mancanegara ke Indonesia Menurut Pintu Masuk [Sumber: Badan Pusat Statistika, 2021, data diolah]

\begin{tabular}{cc}
\hline Tahun & $\begin{array}{c}\text { Kunjungan Wisatawan } \\
\text { Mancanegara ke Indonesia } \\
\text { Menurut Pintu Masuk }\end{array}$ \\
\hline 2017 & 14.039 .799 \\
2018 & 15.811 .305 \\
2019 & 16.106 .954 \\
2020 & 4.052 .923 \\
2021 & 254.230 \\
\hline
\end{tabular}

Tabel 1 menunjukkan adanya pengaruh yang signifikan karena penurunan tingkat kunjungan wisatawan yang dilihat dari jumlah kunjungan wisatawan mancanegara baik dari jalur pintu masuk udara, pintu darat dan pintu laut. Adanya peningkatan yang signifikan tiap tahunnya namun pada masa peralihan tahun 2019 ke tahun 2020 terjadi penurunan yang sangat drastis bahkan hingga memiliki perbedaan jumlah lebih dari 10 juta wisatawan yang berkunjung dan kian menyusut hingga tahun 2021 yang dihitung sejak bulan Januari dan Februari. Penurunan kunjungan disebabkan pada masa penanggulangan awal virus ini menyebar masih terjadinya minim publikasi dan pemahaman masyarakat tentang dampak corona virus (Covid-19) menyebabkan kesalahan fatal hingga tingkat kasusnya semakin melonjak dengan penyebarannya yang sulit terdeteksi. Tentunya dampak krisis terjadi pada bisnis perjalanan yang berkaitan dengan logistik dan transportasi yang menghubungkan dengan ekonomi.

Adanya krisis ekonomi yang berdampak sangat signifikan terhadap suatu eksistensi suatu perusahaan, dan terjadinya krisis karena masa pandemi saat ini dalam krisis tersebut diakui sebagai akibat belum diterapkannya manajemen risiko di suatu perusahaan secara efektif, bahkan banyak perusahaan perusahaan yang belum menerapkan manajemen risiko dalam pelaksanaan penanggulangan Covid-19.

Penanggulangan Covid-19 di Indonesia masih memiliki berbagai kendala dalam mempersiapkan berbagai sarana dan prasarana penunjang serta berbagai kebijakan yang diberikan kepada masyarakat untuk selanjutnya dapat diterapkan dalam kepatuhan protokol kesehatan. Namun masih banyaknya berita yang simpang siur pada awal pandemi Covid-19 dengan kurangnya informasi yang memadai mengakibatkan Pandemi Covid-19 memberi efek ketakutan secara masal yang diakibatkan oleh peningkatan jumlah kasus yang terjadi di dunia dengan hasil banyaknya korban yang disebabkan oleh Covid-19 (Abbas, 2020).

Dalam penanggulangan Covid-19 pemerintah Indonesia memberikan berbagai regulasi dan kebijakan untuk meningkatkan kepatuhan masyarakat baik yang terjadi dalam tingkat individu maupun institusi seperti menjaga jarak, memakai masker dan menghindari kerumunan diikuti oleh senantiasa mencuci tangan. Melalui data yang diunggah oleh Satuan Tugas Penanganan Covid-19 yakni monitoring kepatuhan 
syafruddin, Widaharthana

protokol kesehatan tingkat nasional ditemukan bahwa perilaku masyarakat tak 100\% mendukung kebijakan yang pemerintah buat dalam rangka menanggulangi Covid-19 yang akan dijelaskan melalui table berikut :.

Tabel 2: Tingkat Kepatuhan Memakai Masker

[Sumber: Satuan Tugas Penanganan Covid-19, 2021]

\begin{tabular}{lll}
\hline $\begin{array}{l}\text { Tingkat } \\
\text { Kepatuhan }\end{array}$ & $\begin{array}{l}\text { Jumlah } \\
\text { Pelaksana } \\
\text { (Kabupaten }\end{array}$ & Persentase \\
& /Kota) & \\
\hline$<60 \%$ & 57 & $16.15 \%$ \\
$61-75 \%$ & 63 & $17.85 \%$ \\
$76-90 \%$ & 122 & $34.56 \%$ \\
$91-100 \%$ & 111 & $31.44 \%$ \\
\hline
\end{tabular}

Melalui data tabel 2, maka dapat disimpulkan bahwa dari 353 Kabupaten dan Kota yang terdapat di Indonesia tak semua daerah melaksanakan penanggulangan Covid-19 secara maksimal yang menyebabkan risiko penyebaran Covid-19 semakin mewabah karena kurangnya kesadaran masyarakat untuk menanggulangi Covid bersamasama. Manajemen risiko penting untuk dilaksankan guna melindungi perusahaan terhadap kerugian yang mungkin timbul. Selain itu informasi yang diperoleh dari manajemen risiko sangat bermanfaat bagi pihak- pihak yang terkait, seperti investor, pemasok, kreditur, pemegang saham dan pihakpihak lainnya yang memiliki kepentingan. Informasi mengenai manajemen risiko berguna bagi investor dalam melakukan analisis risiko agar hasil pengembalian yang diharapkan dapat diterima khususnya dalam masa pandemi kini. Berdasarkan latar belakang penulisan di atas, penulis dapat merumuskan permasalahan, yaitu: Bagaimana manajemen risiko mampu mengelola dan meminimalkan risiko yang akan terjadi dalam bisnis perjalanan dalam masa Pandemi Covid19. Adapun tujuan dari penulisan artikel ini adalah untuk menjelaskan konsep manajemen risiko dan cara mengelola risiko di perusahaan ataupun organisasi. Metode penulisan berdasarkan kajian pustaka melalui berbagai literatur yang kemudian dianalisa untuk menemukan solusi dan saran untuk permasalahan tersebut.

\section{METODE PENELITIAN}

Penelitian ini menggunakan metode penelitian kualitatif melalui data netnografi yakni analisis untuk mendalami suatu fenomena pada sebuah kelompok. Netnografi bertujuan untuk memberikan pemahaman global mengenai pandangan dan nilai-nilai masyarakat sebagai cara untuk menjelaskan sikap dan perilaku mengenai fenomena yang terjadi dan dilaksanakan secara online. Subyek penelitian pada penelitian ini adalah pelaku industri perjalanan dan data kementerian Kesehatan mengenai pelaksanaan penanganan maupun penanggulangan Covid-19 untuk dapat ditentukan strategi manajemen risiko pada bisnis perjalanan di masa pandemi Covid-19 melalui data observasi dan studi dokumentasi. Teknik Analisa dengan kualitatif untuk dapat menentukan hasil dan strategi yang tepat mengenai penanggulangan Covid-19 di Indonesia khususnya pada bidang perjalanan

\section{HASIL DAN PEMBAHASAN \\ 3.1 Deskripsi Data}


Penelitian ini mengkaji mengenai strategi manajemen risiko pada bisnis perjalanan di masa pandemi covid-19 melalui data yang dikaji melalui hasil data fenomena Covid-19 untuk menganalisa dampak Covid-19 hingga dapat ditentukan strategi yang tepat yang dapat dilaksanakan berdasarkan pelaksanaan manajemen risiko.

\subsection{Dampak Covid-19 Terhadap Pariwisata di Indonesia.}

Pariwisata merupakan salah satu sektor pariwisata yang terkena dampak paling besar akibat terjadinya wabah pandemi virus corona sejak akhir tahun 2019 lalu yang kemudian memiliki dampak yang menyeluruh ke seluruh belahan dunia mulai dari kesehatan, ekonomi, pembangunan suatu Negara serta tak terkecuali sektor pariwisata. Adanya keputusan mengenai pembatasan sosial serta adanya lockdown di beberapa negara membuat pergerakan masyarakat yang melaksanakan kegiatan atau aktifitasnya dalam kehidupan sehari-hari terbatas. Hal ini pun terjadi pada sektor pariwisata, berbagai pembatasan di berbagai Negara kemudian menyebabkan adanya pengurangan aktivitas dalam menjalankan perjalanan wisata sehingga banyak wisatawan yang menolak atau membatalkan perjalanannya menuju suatu daerah pariwisata.

Bali merupakan salah satu daerah pariwisata yang tiap tahunnya memiliki jutaan tamu mancanegara yang dengan senang hati mengunjungi dan menghabiskan waktunya di Bali. Namun karena pandemi Covid-19 ini Bali telah kehilangan sumber penghasilan utamanya karena Bali mengandalkan pariwisata dan tingkat hunian suatu akomodasi untuk dikelola sebagai penghasilan daerah. Hal ini pun tak hanya berdampak pada pemerintahan saja, namun juga berdampak pada para pelaku usaha pariwisata.

Fakta bahwa adanya penurunan minat perjalanan wisata oleh wisatawan menyebabkan adanya penurunan super drastis dari devisa hingga occupancy serta jumlah tamu yang datang ke Bali. Hal ini dapat dilihat melalui data Badan Pusat Statistika yang berkaitan dengan jumlah penumpang pesawat di Bandara Internasional I Gusti Ngurah Rai dalam melaksanakan penerbangan internasional dengan adanya penurunan tajam dari wisatawan mancanegara melalui jalur pesawat yang akan dijabarkan melalui tabel berikut :

Tabel 3: Jumlah Kunjungan Wisatawan Mancanegara pada Bandara Internasional I Gusti Ngurah Rai

[Sumber: Badan Pusat Statistika, 2021, data diolah]

\begin{tabular}{cc}
\hline Tahun & Jumlah Penumpang Pesawat Internasional \\
\hline 2017 & 5.628 .248 \\
2018 & 6.025 .760 \\
2019 & 6.245 .543 \\
2020 & 1.059 .198 \\
2021 & 14 \\
\hline
\end{tabular}

Melalui tabel 3 menunjukkan adanya pengaruh yang signifikan karena penurunan tingkat kunjungan wisatawan yang dilihat dari jumlah penumpang pesawat internasional dapat dilihat dari perbedaan jumlah kunjungan dari tiap tahunnya yang kian meningkat namun pada masa peralihan tahun 2019 ke tahun 2020 terjadi penurunan yang sangat drastis bahkan dapat dikatakan pariwisata bali melalui jalur kunjungan wisatawan mengalami kerugian 500\% dari total kunjungan sebelumnya

Pandemi Covid-19 telah memberikan kerugian yang berpengaruh pada berbagai sektor, tak hanya bidang 
pariwisata saja namun ke sektor perekonomian lainnya. Hal ini terjadi karena pada masa penanggulangan awal virus ini menyebar masih terjadinya minim publikasi dan pemahaman masyarakat tentang dampak corona virus Covid-19 menyebabkan kesalahan fatal hingga tingkat kasusnya semakin melonjak dengan penyebarannya yang sulit terdeteksi.

\subsection{Kunjungan Wisatawan Sebelum Datangnya Covid-19.}

Aktivitas pariwisata memiliki keterkaitan dengan lajur ekonomi yang berada pada daerah wisata yang saling memiliki keterkaitan dalam penyediaan, produksi serta layanan yang melibatkan usaha kecil, usaha akomodasi hingga pemerintah namun pada masa pandemi covid-19, ekonomi telah luluh lantak sehingga sektor pariwisata terpaksa dihentikan karena tak adanya kunjungan dan kegiatan operasional yang dilaksanakan. banyak daerah wisata serta berbagai akomodasi yang terdapat di Bali mengalami penurunan tingkat okupansi yang cukup signifikan akibat penurunan jumlah kunjungan wisatawan.

Tak adanya pemasukan yang pasti serta didukung oleh biaya operasional yang besar menyebabkan banyak akomodasi maupun usaha yang berkaitan dengan pariwisata di Bali menutup usahanya yang mengakibatkan banyaknya pekerja hotel dirumahkan hingga waktu yang belum ditentukan serta menyebabkan perlambatan pertumbuhan ekonomi daerah tak terkecuali Pulau Bali. Padahal sebelumnya sektor pariwisata khususnya Pulau Bali merupakan keunggulan Indonesia karena terus meningkatnya wisatawan yang berkunjung tiap tahunnya. Namun penurunan terjadi akibat Pandemi Covid-19. Hal ini dikemukakan dalam hasil data Badan Pusat Statistik bahwa adanya penurunan yang drastis dari tahun 2019 ke 2020 untuk jumlah kunjungan wisatawan mancanegara yang berkunjung ke Bali yakni sebagai berikut :

Tabel 4: Tingkat Hunian Kamar pada Provinsi Bali [Sumber: Badan Pusat Statistika, 2021]

\begin{tabular}{cc}
\hline Tahun & Tingkat Hunian Kamar \\
\hline 2016 & $61,75 \%$ \\
2017 & $62.89 \%$ \\
2018 & $65.13 \%$ \\
2019 & $59.57 \%$ \\
2020 & $15.61 \%$
\end{tabular}

Berdasarkan data tabel 4 dijelaskan bahwa adanya penurunan drastis yang terjadi dalam tingkat hunian kamar di berbagai akomodasi pada daerah Bali baik pada hotel berbintang maupun non berbintang. Daerah yang kerap dikunjungi oleh wisatawan seperti Ubud, Nusa Dua, Uluwatu, Jimbaran dan berbagai destinasi lainnya telah kehilangan tingkat huni wisatawan sehingga tak adanya sumber pendapatan yang berpengaruh pada sektor pariwisata terhadap perekonomian di Indonesia. Selain sebagai sumber pendapatan devisa, pariwisata juga memberikan kontribusi untuk penciptaan lapangan kerja, kegiatan produksi dan pendapatan nasional (PDB), pertumbuhan sektor swasta dan pembangunan infrastruktur. Pariwisata juga memiliki faktor lain dalam pendapatan yang diperoleh melalui pajak. Sehingga wabah pandemi Covid19 menyebabkan adanya kelesuan dan pesimisme dari pelaku pariwisata dalam menanggapi masa depan pariwisata selanjutnya terutama pada daerah yang mengandalkan pariwisata sebagai pemasukan daerahnya. Salah satu penelitian yang telah mengkaji mengenai 
dampak menurunnya sektor ekonomi pariwisata telah dikaji dalam penelitian yang dilaksanakan oleh Revindo dkk (2020) pada kajian LPEM FEB UI bahwa sektor ekonomi tak hanya mengalami kerugian pada sektor pariwisata saja namun berbagai sektor yang saling memiliki keterkaitan didalamnya melalui data berikut :

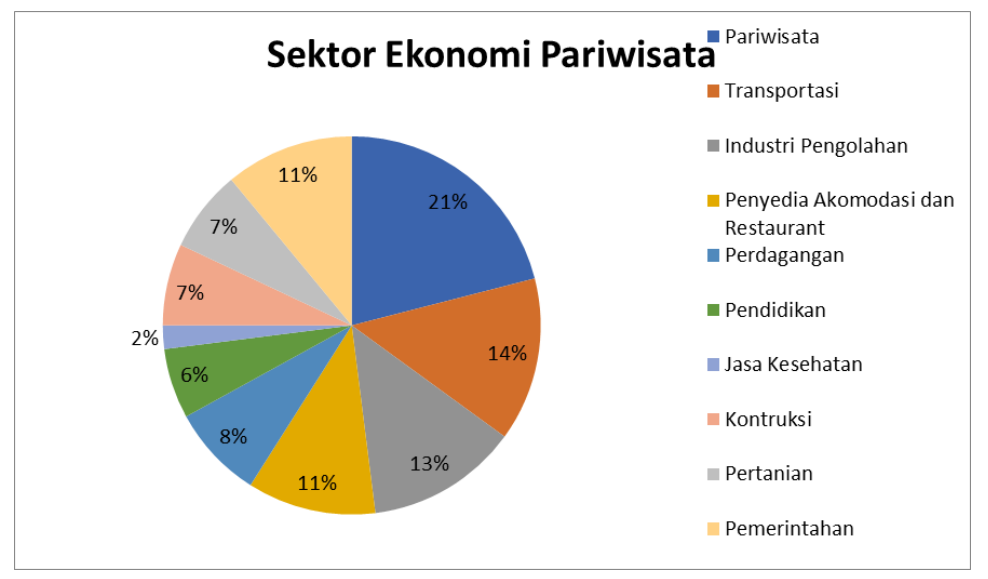

Gambar 2: Dampak Covid-19 pada Berbagai Sektor Ekonomi [Sumber: CEIC, 2020 (data diolah)]

Melalui grafik diatas maka berbagai sektor yang berkaitan dengan pariwisata dan terdampak Covid-19 paling besar adalah Industri Pengolahan yang diakibatkan oleh disrupsi global supply chain, Industri Transportasi yang disebabkan oleh berkurangnya aktifitas pariwisata dan akibat pembatasan perjalanan, Penyediaan Akomodasi dan Restoran yang diakibatkan oleh pembatasan perjalanan, Perdagangan yang disebabkan oleh daya beli masyarakat dan penerapan PSBB. Sehingga guna menanggulangi kerugian yang semakin berkepanjangan pemerintah melaksanakan strategi sesuai arahan WHO (2020) dalam memberikan pedoman transisi menuju the new normal atau kehidupan baru, yang telah dilaksanakan pertanggal 29 Mei 2020 secara resmi bahwa Indonesia mengumumkan pemberlakuan masa New Normal dan ditandai dengan pelonggaran aktivitas sosial yang ada di daerah-daerah dan tetap menekankan penerapan physical distancing.

Manajemen risiko sangat penting untuk diterapkan sebagaimana yang telah dijelaskan oleh Kasidi bahwa salah satu penyebab risiko dapat terjadi adalah faktor bencana yang menyebabkan terjadinya kerugian karena adanya wabah penyakit yang terjadi di dunia seperti contohnya Pandemi Covid-19 ini. Dunia perjalanan atau pariwisata yang berkaitan dengan pendapatan Negara kurang mengalami penanggulangan dengan baik dan benar menyebabkan terjadinya kerugian massal dan semakin meningkat sehingga pemerintahpun mulai membuka kembali wisata namun hanya dalam ruang lingkup wisatawan nusantara.

\subsection{Cara Penanggulangan Risiko Binis Perjalanan}

Setiap perusahaan pasti memiliki sumber risiko yang kemungkinan akan terjadi tergantung pada usaha dan jenis risiko yang dijalankan. Bagi Negara Indonesia, penanggulangan risiko yang terjadi dibidang pariwisata memerlukan adanya kerjasama antar pemerintah dan pelaku pariwisata serta masyarakat yang dimulai dari adanya penyediaan dalam fasilitas pekerja dalam industri Kesehatan serta Pemerintah Indonesia memberikan dana bantuan seperti Bantuan Langsung Tunai dan pemberian tunjangan pariwisata dan potongan subsidi listrik kepada masyarakat untuk 
menunjang perekonomian. Tentunya dalam menunjang kegiatan pariwisata dan bisnis perjalanan merupakan suatu tantangan besar karena perlu dilaksanakan berbagai regulasi ketat untuk menghindari perluasan penyebaran virus semakin parah dan tak terkendali sehingga dalam menanggulanginya dilaksanakan melalui beberapa cara berikut :

1) Dalam pelaksanaan PSBB yang mengakibatkan kerugian manajemen bisnis perjalanan yang tidak memperbolehkan adanya kontak fisik yang terlalu riskan guna menghindari penyebaran virus dalam ranah lingkup berwisata maka perusahaan dapat menggunakan media sosial maupun media internet yang dipergunakan dalam strategi promosi sebagai terobosan pemasaran produk maupun jasa yang dimiliki yang disesuaikan oleh kebutuhan wisatawan dengan melaksankan kegiatan berdasarkan adaptasi pendekatan berbasis pengguna (userbased approach) sebagai upaya untuk meningkatkan kualitas produk dengan menyesuaikan selera wisatawan yang membutuhkan rasa aman dari kekhawatiran terpapar virus Covid-19, mengingat pariwisata sudah menjadi kebutuhan dan gaya hidup.

2) Dalam rangka mengendalikan penyebaran Covid-19 pelaksanaan vaksinasipun dijalankan melalui adanya pengendalian administratif dengan memprioritaskan pelaku kesehatan publik, pariwisata dan lansia dalam pelaksanaannya dengan adanya jumlah masyarakat yang telah divaksin aalah 11.101.291 penduduk. Pelaksanaan vaksinasi dijalankan untuk mengurangi dampak penyebaran dengan memanipulasi sistem imun masyarakat untuk kebal akan virus covid-19 melalui pengujian klinis.

3) Layanan kesehatan merupakan garda terdepan dalam menanggulangi risiko pandemi Covid-19 ini maka dalam pelaksanaannya dilaksanakan percepatan penanganan Covid-19 melalui APBD pemerintah untuk menyiapkan sarana dan prasarana baik berupa APD, Gedung yang memadai hingga jumlah kasur untuk pasien terdampak sehingga berbagai insentif yang diberikan diharapkan dapat memberi pengurangan risiko masyarakat terdampak yang kemudian akan berkaitan dengan pertumbuhan ekonomi dan kepercayaan wisatawan asing dalam penanganan Covid-19 di Indonesia.

4) Melaksanakan Protokol Kesehatan pada Akomodasi maupun Layanan Pariwisata seperti pemeriksaan suhu harian untuk semua karyawan, menyemprotkan disinfektan pada berbagai fasilitas umum, meningkatkan pelatihan keselamatan kesehatan untuk semua staff pariwisata, pelatihan yang ditingkatkan untuk pembersihan kamar tamu dan umum area, menetapkan prosedur pembersihan baru, dan menerapkan praktik jarak sosial di tempat umum.

5) Tindakan lain adalah peninjauan dan penyesuaian semua area dengan peralatan dan fasilitas tamu bersama yakni menyediakan fasilitas yang menunjang protokol kesehatan saat wisatawan berkunjung ke destinasi, diikuti oleh pengurangan kuota dalam kapasitas menginap atau berkunjung agar pelaksanaan jarak antar pengunjung dilaksanakan dengan disiplin.

6) Mempromosikan destinasi pariwisata domestik atau mengubah arah wisatawan dalam melaksanakan destinasi ke suatu daerah baru yang tidak banyak dikunjungi sebelumnya sehingga risiko penumpukan wisatawan akan berkurang. Jika dikaitkan dalam bahasan manajemen risiko maka dibutuhkan adanya pelaksanaan model pariwisata yang berkualitas dibandingkan pariwisata masal terlebih lagi dikondisi saat ini. Menurut Astawa, pariwisata yang 
syafruddin, Widaharthana

berkualitas indikatornya adalah kunjungan wisatawan itu bisa berkali-kali tidak hanya sekali saja. Dan memiliki standar. Semuanya harus terstandar, mulai dari pedagang di objek wisata, destinasi wisata, hotel, transportasi dan guide pariwisata.

Pariwisata berbasis alam pedesaan merupakan salah satu jawaban terbaik yang dapat digunakan melalui pengelolaan lembaga baik daerah maupun desa. Wisatawan dapat diajak menelusuri desa dan memperhatika kehidupan warga desa sehingga selain menjadi inovasi yang menarik, model wisata jenis ini memberikan gambaran lain mengenai sikap masyarakat setempat dalam menannggapi Covid-19 di pedesaan. Pariwisata dengan memanfaatkan alam pedesaan memiliki potensi lebih rendah dibandingkan man made yang mengumpulkan masa dalam kondisi pandemi kini sehingga penyebaran melalui kegiatan pariwisata akan berkurang dibandingkan pariwisata masal.

\section{KESIMPULAN}

Bisnis perjalanan merupakan salah satu bisnis yang terkena efek Pandemi Covid-19 yang menyebabkan kerugian yang diakibatkan oleh faktor eksternal perusahaan. Runtuhnya perekonomian bidang perjalanan maupun pariwisata disebabkan oleh kurangnya informasi dan pemahaman akan penanggulangan Covid-19 yang baru terkuak ketika jumlah korban sudah membludak. Hal ini tentunya membutuhkan manajemen risiko yang perlu untuk dilaksankan guna melindungi perusahaan terhadap kerugian yang timbul. Manajemen Risiko dilaksanakan guna mendapatkan hasil mengenai permasalahan yang terjadi melalui proses identifikasi dan pengukuran akan risiko yang terjadi sehingga dapat ditemukan hasil dan strategi untuk mengelola risiko tersebut. Salah satu daerah yang terdampak paling besar adalah Pulau Bali yang telah menyebabkan kerugian besar karena
Bali kehilangan sumber penghasilan utamanya karena Bali mengandalkan pariwisata dan tingkat hunian suatu akomodasi untuk dikelola sebagai penghasilan daerah. Hal ini pun tak hanya berdampak pada pemerintahan saja, namun juga berdampak pada para pelaku usaha pariwisata. Sektor pariwisata memberikan kontribusi besar pada pendapatan Indonesia yang didapat melalui penerimaan devisa, pendapatan daerah, penyerapan investasi serta tenaga kerja maupun pengembangan wilayah sehingga dampak karena adanya wabah virus corona ini sangatlah besar sehingga dalam menanggulangi risiko yang terjadi dilaksanakan sesuai dengan Hierarki Pengendalian Bahaya dengan adanya penerapan Alat Pelindung Diri baik dari tenaga kesehatan dan masyarakat untuk mencapai tujuan nasional dalam menciptakan efektivitas penanggulangan covid-19. Selain itu dengan menggeser model pariwisata menjadi Pedesaan atau alam dapat memperkecil ruang lingkup dalam kerumunan namun tetap terlihat menarik dengan berbagai pengemasan kegiatan yang dilaksanakan oleh pelaku pariwisata di desa. Pariwisata dengan memanfaatkan alam pedesaan memiliki potensi lebih rendah dibandingkan man made yang mengumpulkan masa dalam kondisi pandemi kini sehingga penyebaran melalui kegiatan pariwisata akan berkurang dibandingkan pariwisata massal.

\section{DAFTAR PUSTAKA}

Abbas, E. W., Handy, M. R. N., Shaleh, R. M., \& Hadi, N. T. F. W. (2020). Ecotourism of Martapura River Banjarmasin as a Learning Resources on Social Studies. The Innovation of Social Studies Journal, 1(2), 111-119.

Badan Pusat Statistika. (2021). Banyaknya Wisatawan Mancanegara Bulanan ke Bali Menurut Pintu Masuk (Orang) 2016-2020 2019. Diambil kembali pada 28 Maret 2020, dari 
syafruddin, Widaharthana

bps.go.id:https://bali.bps.go.id/indic ator/16/129/2/banyaknya-

wisatawan mancanegara-kebalimenurut kawasan.html

Badungnews. (2020).Pasca Pandemi, Bali Terapkan Wisata Berkualitas. Siberindo. Diakses pada 27 april 2021, dari https://bali.siberindo.co/24/10/20 20/pasca-pandemi-bali-terapkanwisata-berkualitas/

BBC Indonesia. (2020). Tak Lagi Andalkan Pariwisata, Warga Sebuah Desa di Bali Beralih Jadi Petani Saat Pandemi. Kompas. Diakses pada 27 april 2021, darihttps://regional.kompas.com/re $\mathrm{ad} / 2020 / 08 / 26 / 06070081 /$ taklagi-andalkan-pariwisata-wargasebuah-desa-di-bali-beralih-jadipetani?page $=$ all

CEIC. (2020). Indonesia Premium Database. Retrieved March 27 2021, from https://insights.ceicdata.com/node/ INDONESIA_TP86933

Chebli, A. (2020). "The Impact Of Covid19 On Tourist Consumption Behaviour : A Perspective Article, Journal of Tourism Management Research Vol. 7. No. 2 pp. 196207

https://www.researchgate.net/publ ication/343058098

Jiang, Y \& Wen, J. (2020). Effects of Covid 19 on hotel marketing and management: A perspective article. International Journal of Contemporary Hospitality Management.https://www.research gate.net/publication/341611962_Ef fects_of_COVID19_on_hotel_marketi ng_and_management_A_perspective article/link/5b0e50a6fdcc90d696e B9c/Download Covid19.Kasidi.(2010).Manajemen Risiko.Bogor: Ghana.

Kemenparekraf. (2019) Neraca Satelit Pariwisata Nasional 2017. Retrieved March 27 2021, from http://www.kemenparekraf.go.id/p ost/neraca-satelit-pariwisatanasional 2017

Keputusan Menteri Kesehatan No HK.01.07/MENKES/382/2020 tentang Protokol Kesehatan Bagi Masyarakat di Tempat dan Fasilitas Umum Dalam Rangka Pencegahan COVID-19

Shaw, G.K. (2010). A risk management model for the tourism industry in South Africa. Thesis. South Africa : North West University 